\title{
Analytical Hierarchy Process Method Based Analysis on Road Safety Inspection at Metu - Yayo Road Segment
}

\author{
Dawit Ayenachew, Sinshaw Sahile, Garomsa Fikadu \\ Department of Civil Engineering, Metu University, Metu Town, Ethiopia \\ Email address: \\ devid.anw2009@yahoo.com (D. Ayenachew), Sinishaw13sahile@gmail.com (S. Sahile), Garomsa2020@gmail.com (G. Fikadu)
}

\section{To cite this article:}

Dawit Ayenachew, Sinshaw Sahile, Garomsa Fikadu. Analytical Hierarchy Process Method based Analysis on Road Safety Inspection at Metu - Yayo Road Segment. International Journal of Transportation Engineering and Technology. Vol. 7, No. 1, 2021, pp. 1-11. doi: $10.11648 /$ j.ijtet.20210701.11

Received: December 25, 2020; Accepted: January 14, 2021; Published: January 22, 2021

\begin{abstract}
Now days road safety becomes a worldwide concern. Similarly Road safety risk has been a major issue in the study area (Metu- Yayo road segment). The successful assessments of road safety inspection within the study area are very essential to minimize future road accidents faced by the entire road user. The study were started by examining the current condition of the road using road safety inspection manual then it used focus group judgments and it is analyzed by analytical hierarchical process method based pairwise comparison in identification of contributing factors for the road safety risk using two levels of Analytical Hierarchical process, and four major factors i.e. pavement surface condition, road geometry condition, road side environment condition, road traffic control condition, and also it tries to prioritize the road section to identify the road with better facilities and the road in the worst condition. During road safety inspection in the study area the road experience early stages of pavement distresses, road traffic sign related problems, sight distance obstruction, and soil slide related problems this in turn speeds up the road safety risk and increases the occurrence of road traffic accidents. As a result, this study concluded, road traffic control factors were the most significant factors which contributes to the occurrences of road safety risk. In comparison, Lakosaya to Yayo road section is the found in a better condition, but the road section from Mechi to Lakosaya is found in worse condition in the study area.
\end{abstract}

Keywords: Accident, Analytical Hierarchy Process, Pavement Surface, Road Safety, Road Safety Risk

\section{Introduction}

Now, All over the world road traffic accident is a challenging problem. In undeveloped countries with $1 \%$ of registered vehicles there is $16 \%$ of road traffic deaths were recorded but the rest of $74 \%$ road traffic deaths happened in middle-income countries. Therefore, low and middle-income countries faced $90 \%$ of road accident deaths [1]. Depending on the world health organization road accident modeled numbers 2009, the 10 countries were figured out with the high number of peoples' death these are: China, India, Nigeria, the United States, Pakistan, Indonesia, the Russian federation, Brazil, Egypt and Ethiopia [2]. Good road conditions should offer a better service to road user, but sometimes controlled information along a given route was not enough and not too much. It is necessary to release informative guide line and guidance which is necessary to strengthen the massage for a road user. And forgive them if the principles failed [3]. The government of Ethiopia gives priority in provision of infrastructure development to increase and expand the road safety in the transportation sectors for $20.3 \%$ of populations settlers in the urban areas out of the total population 103,232,590 living in Ethiopia. The numbers of registered vehicles of all categories are 394, 001 [4]. As recent research study reveals that around $34 \%$ of crashes were recorded in urban area due to road way condition factors. To alleviate this problem the road safety reactive approach method of safety improvement interventions were taken after the road is already vulnerable to road accidents. Many countries exercise reactive approach method based as road safety prevention tool but fails to improve their road safety problem due to the need to have required written standard approach. So other proactive approach intervention is needed i.e. proactive Road Safety Inspection (RSI) for developing countries which is the new method to encounter road safety problem before road 
accident happened [5].

\section{Statement of the Problem}

Along Metu to Yayo road segment still there is no regular road safety inspection since it is opened for the service. Ethiopian Road Authority developed road safety inspection manual, but the government stockholder cannot carry proactive road safety inspection out even once a time period due to this reason different road way factors the road is now under vulnerable to road infrastructure safety problem this causes i.e. road traffic accident.

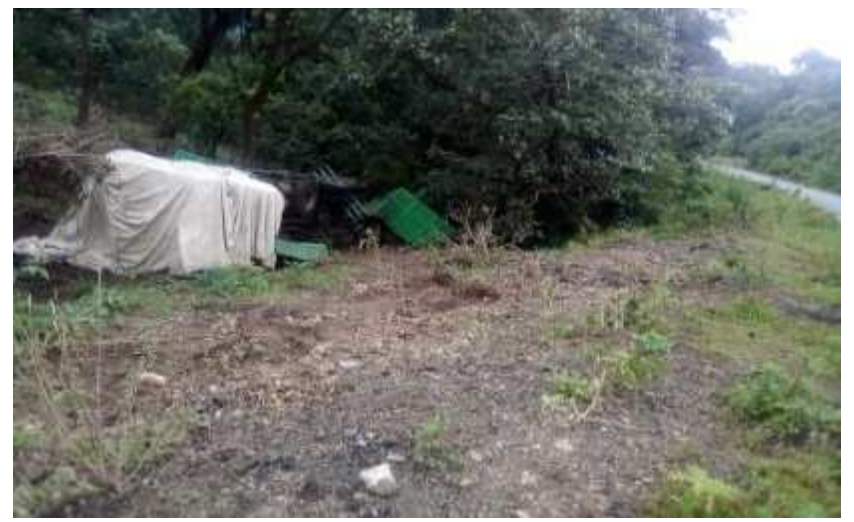

Figure 1. Truck accident due to soil slide along the road shoulder near the entrance of Hurumu village.

\section{Objectives of the Research}

\subsection{General Objective}

To conduct road safety inspection using Analytical Hiearchy Process

\subsection{Specific Objectives}

1) To examine the current road safety condition of the study area.

2) To identify the Significant factors which contributes for road safety risk

3) To prioritize the road section according to road safety inspection need.

\section{Research Questions}

1. What are the current conditions of road safety problems in the study area?

2. What are the most significant factors contributing for road safety risk in the study area?

3. What are the specific counter measures taken to minimize the road safety risk in the study area?

\section{Significance of the Study}

The significance of this research are: to reduce the accident happening through the introduction of regular proactive road safety inspection and solution measures taken, to use as a reference document for the road safety audit team and organization this reduces costs allotted for feasibility study at the study area.

\section{Literature Review}

RSA is defined as a systematic road safety assessment tool which incorporates road traffic safety knowledge into road planning and design to prevent road traffic accidents [6]. Road safety audit with clear concept perceive road safety audit suite tool which is intended to improve road safety with good quality control [7]. Road safety audit begin in United Kingdom and have been used for more than twenty years. The United Kingdom advanced the application of road safety audit where it mandatory for all trunk road improvement projects and road safety audit monitoring process [8]. Various countries used road safety audit manuals to rank or to prioritize road sections for conducting road safety inspection among them ranking by reduction potential and ranking by accident density used in Vienna, ranking by accident rate in used USA in 2007. Ranking by reduction potential determined using both accident and accident cost and also include severity of the accident in the assessment but involves complex calculation, ranking by accident density extensively used where high accident concentration are covered, but it depends on heavily on the selected section of the road [9]. Many countries have road safety inspection, but do not have fixed period of road safety inspection frequency due to lack of legal frame work to inspect the road safety. Hungary and Portugal implemented once in every five years and once in every two years in Germany [10]. According to [11] the study aims to inspecting road related scenario, safety measures, using traffics volumetric data and real time potholes data collection, questionnaire survey, but the data were analyzed based on field observation data and questionnaire survey data. Similarly [12] analyzes the factors affecting rural road safety due to vehicle related, road environment factor and the other vehicle related factors, depending these factors the study summarizes and provide mitigation for provision of safety for rural road safety. Road safety inspections and the star rating of existing roads provide a mechanism to identify any existing road design and speed management features that can affect crash likelihood and severity [13].

\section{Research Methodology}

\subsection{Description of the Study Area}

The study area is located in geographic coordinates of the two terminal points are near Metu town (commencement of the study area) has a latitude and longitude of $8^{\circ} 18^{\prime} \mathrm{N}$ $35^{\circ} 35^{\prime} \mathrm{E}$, and an altitude of 1605 meters and near Yayo town (where the route ends) has a latitude and longitude of $8^{\circ} 0^{\prime} 42^{\prime} \mathrm{N}-\quad 8^{\circ} 44^{\prime} 23^{\prime} \mathrm{N}, \quad 35^{\circ} 20^{\prime} 31^{\prime \prime} \mathrm{E}-\quad 36^{\circ} 18^{\prime} 20^{\prime \prime} \quad$ E. respectively, with an altitude of 1670 meters. Metu to Yayo flexible Asphalt road width varying from $6 \mathrm{~m}$ to $7 \mathrm{~m}$ and $12 \mathrm{~m}$, with minor and major drainage structures, which is $30 \mathrm{~km}$ in 
length and accessible during wet seasons with fair ride rainfall areas of Ethiopia. ability. This road section is agriculturally rich and heavy

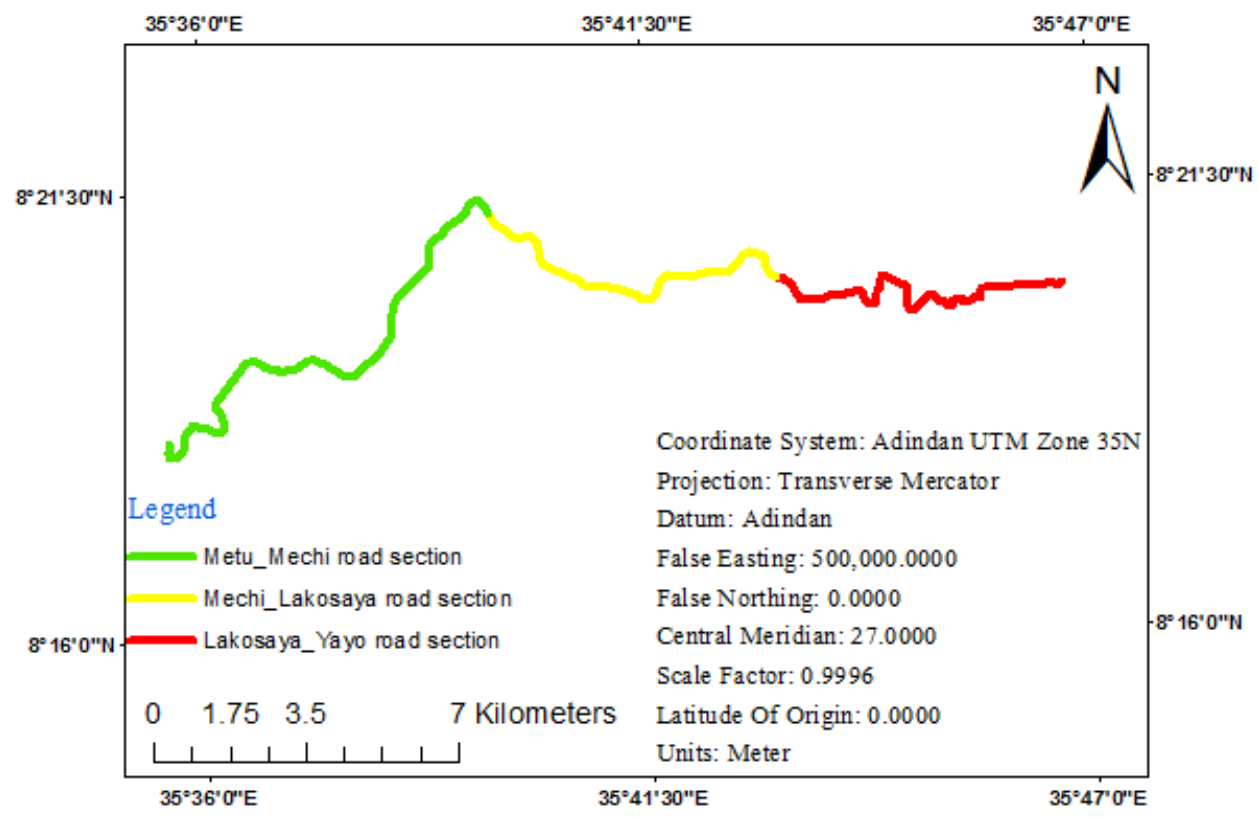

Figure 2. Map of the study area.

\subsection{Study Population}

In this research work the targeted populations study groups were current road conditions and factors that contribute to future road safety risk in the study area.

\subsection{Sources of Data and Method Data Analysis}

During field observation Ethiopian road authority road safety inspection manual was used to record and examine the current road condition, after that the questionnaires were developed in favor of Ethiopian Road Authority (ERA) road safety inspection manual with respect to the four decision criteria and distributed for eight people to receive their judgment since it is recommended by the review of $\mathrm{A}$. Richard Krueger's 'designing and conducting focus group interview' to take six up to eight people. Depending on these focus group judgment pair wise comparison matrixes were developed and further (level 1 and level 2) analysis done using Analytical Hierarchy Process (AHP) to identify significant factors which contribute the road safety risk and to prioritize the road section.

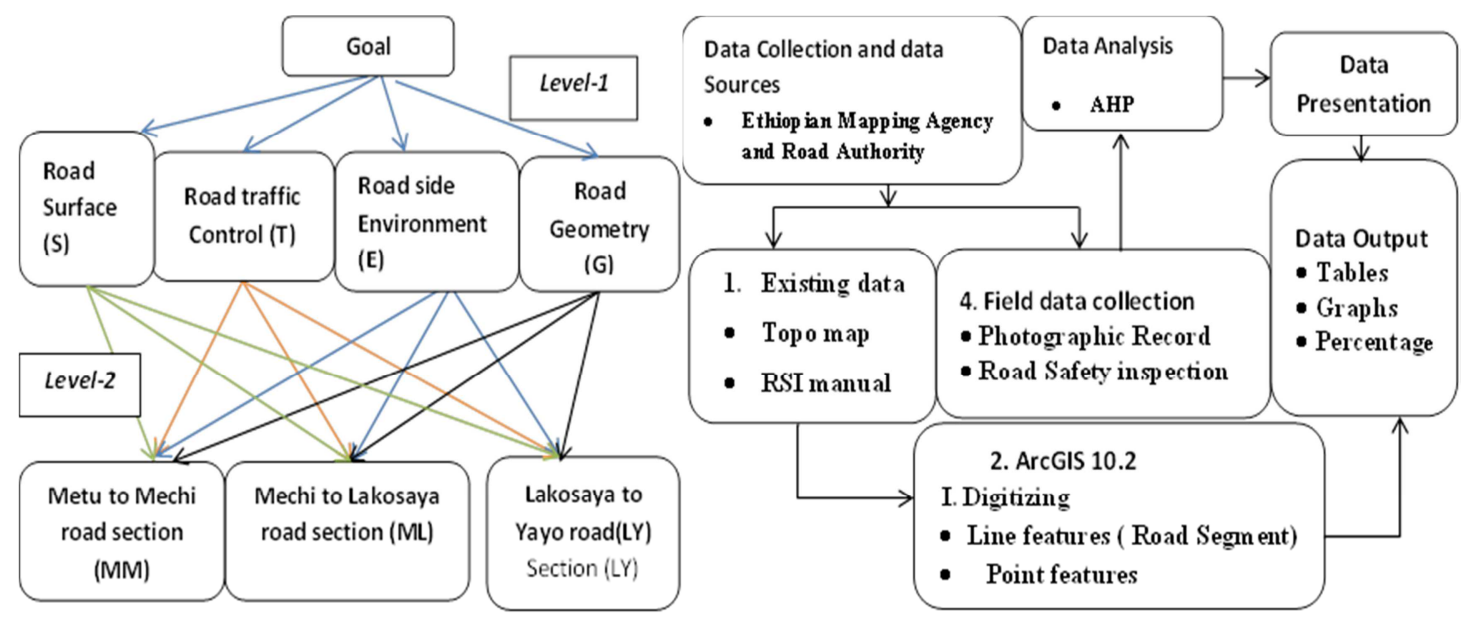

Figure 3. Decision making process and Research design.

AHP extension was integrated with ArcGIS 10.2 software to compute the parameters which are used latter for decision making but these data cannot be generated easily. Therefore, MS-Excel template was developed to analysis AHP, by using the following steps.
Step 1: Collect and organize the focus group judgments into square matrix $(M)$ form and all columns of the square matrix are summed. 


$$
M=\begin{array}{cccc}
\text { level } & A & B & C \\
A & 1 & a & b \\
B & \frac{1}{a} & 1 & c \\
C & \frac{1}{b} & \frac{1}{c} & 1 \\
& \text { *sum } & \frac{a+b+1}{a b} & \frac{a+c+1}{c} b+c+1
\end{array}
$$

Step 2: Each cell of the column is by the sum of its own column.

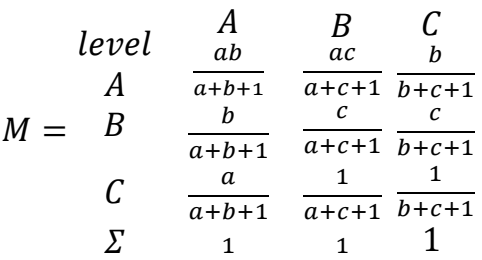

Step 3: Depending on the value obtained from Step2 each cell in the raw were summed up.

$$
\begin{array}{cccccc}
\text { level } & A & & B & C & \\
A & \frac{a b}{a+b+1} & & \frac{a c}{a+c+1} & \frac{b}{b+c+1} & \frac{a b(a+c+1)(b+c+1)+a c(a+b+1)(b+c+1)+b(a+b+1)(b+c+1)}{(a+b+1)(a+c+1)(b+c+1)} \\
B & \frac{b}{a+b+1} & \frac{c}{a+c+1} & \frac{c}{b+c+1} & \frac{b(a+c+1)(b+c+1)+c(a+b+1)(b+c+1)+c(a+b+1)(a+c+1)}{(a+b+1)(a+c+1)(b+c+1)} \\
C & \frac{a}{a+b+1} & \frac{1}{a+c+1} & \frac{1}{b+c+1} & \frac{a(a+c+1)(b+c+1)+(a+b+1)(b+c+1)+(a+b+1)(a+c+1)}{(a+b+1)(a+c+1)(b+c+1)} \\
\Sigma & 1 & 1 & 1 & 3
\end{array}
$$

Step 4: The priority vectors were computed.

$$
\mathrm{PV}=\frac{S U M}{n}
$$

Where the ' $\mathrm{n}$ ' the judgment matrix order.

Step 5: Computation of the maximum Eigen value of the judgment matrix $(\lambda \max )$.

$$
\lambda \max =\left(*_{\text {sum }} x P V\right)
$$

Step 6: For the judgment matrix order ' $\mathrm{n}$ ' consistency index $(\mathrm{CI})$ is determined.

$$
C I=\left(\frac{\lambda_{\max } n}{n-1}\right)
$$

Step 7: The value of consistency index is subjective to and failed to compare the judgment matrix to do so professor Saaty proposed the random consistency ratio (RI), and finally he developed the consistency ratio (CR). The threshold value of the consistency ratio is not greater 0.1 and the value of random consistency ratio (RI) is taken from table 1 .

$$
C R={ }_{R I}^{C I}
$$

Overall consistency of the analytical hierarchy is checked using the ratio of weighted consistency index (CI) and weighted random consistency index (RI) to decide whether the composite weight/ the hierarchy is consistent or not. The overall weighted consistency ratio is computed using the

\begin{tabular}{|c|c|c|}
\hline Intensity of importance & Definition & Explanation \\
\hline 1 & Equal importance & Two activities contribute equally to the objective \\
\hline 2 & Weak/slight & \multirow{2}{*}{ Experience and judgment slightly favor one activity over another } \\
\hline 3 & Moderate importance & \\
\hline 4 & Moderate plus & \multirow{2}{*}{ Experience and judgment strongly favor one activity over another } \\
\hline 5 & Strong importance & \\
\hline 6 & Strong plus & \multirow{2}{*}{ An activity is strongly favored and its dominance demonstrated in practice } \\
\hline 7 & Very strong/Demonstrated importance & \\
\hline 8 & Very Very strong & \multirow{2}{*}{$\begin{array}{l}\text { The evidence favoring one activity over another is of the highest possible } \\
\text { order of affirmation }\end{array}$} \\
\hline 9 & Extreme importance & \\
\hline $\begin{array}{l}\text { Reciprocals of above none } \\
\text { zero }\end{array}$ & $\begin{array}{l}\text { If activity } i \text { has one of the above nonzero numbers } \\
\text { assigned to it when compared with activity } j \text {, then } j \\
\text { has the reciprocal value when compared with } i\end{array}$ & A reasonable assumption. \\
\hline $1.1-1.9$ & If the activities are very close & $\begin{array}{l}\text { May be difficult to assign the best value but when compared with other } \\
\text { contrasting activities the size of the small numbers would not be too noticeable, } \\
\text { yet they can still indicate the relative importance of the activities }\end{array}$ \\
\hline
\end{tabular}
following equation.

$$
C R w=\frac{\Sigma W i \cdot C I i}{\Sigma W i \cdot R I}
$$

Table 1. Random consistency index [14].

\begin{tabular}{lllllllllll}
\hline $\mathbf{N}$ & $\mathbf{1}$ & $\mathbf{2}$ & $\mathbf{3}$ & $\mathbf{4}$ & $\mathbf{5}$ & $\mathbf{6}$ & $\mathbf{7}$ & $\mathbf{8}$ & $\mathbf{9}$ & $\mathbf{1 0}$ \\
\hline $\mathrm{RI}$ & 0 & 0 & 0.58 & 0.9 & 1.12 & 1.24 & 1.32 & 1.41 & 1.45 & 1.49 \\
\hline
\end{tabular}

Table 2. The intensity of importance number. [15] 


\section{Result and Discussion}

\subsection{The Road Condition at the Study Area}

There were a total of three road sections with a total length of around $30 \mathrm{~km}$. The over all condition of the road in the study area are identified during field survey. The case of road safety problem needs to be examined in terms of four decision criteria i.e. Geometry, traffic control, road surface, and road side environment of the road section in the road segment.

\subsubsection{Metu to Mechi Road Section Condition}

This section of road is the first part Metu to Yayo road segmet which commences from metu town near sedest meto located at the coordinates $(78593.407,919122.769)$ and ends with Mechi which is located at the coordinates (793145.391, 923972.983). As shown in the description and figure illustration section (see table 3) some problems were observed among these pavement distress i.e. Early stage of alligator types of cracking, pothole, disintegration of aggregate and bitumen, undulated pavement surface and some of road traffic problem were seen.

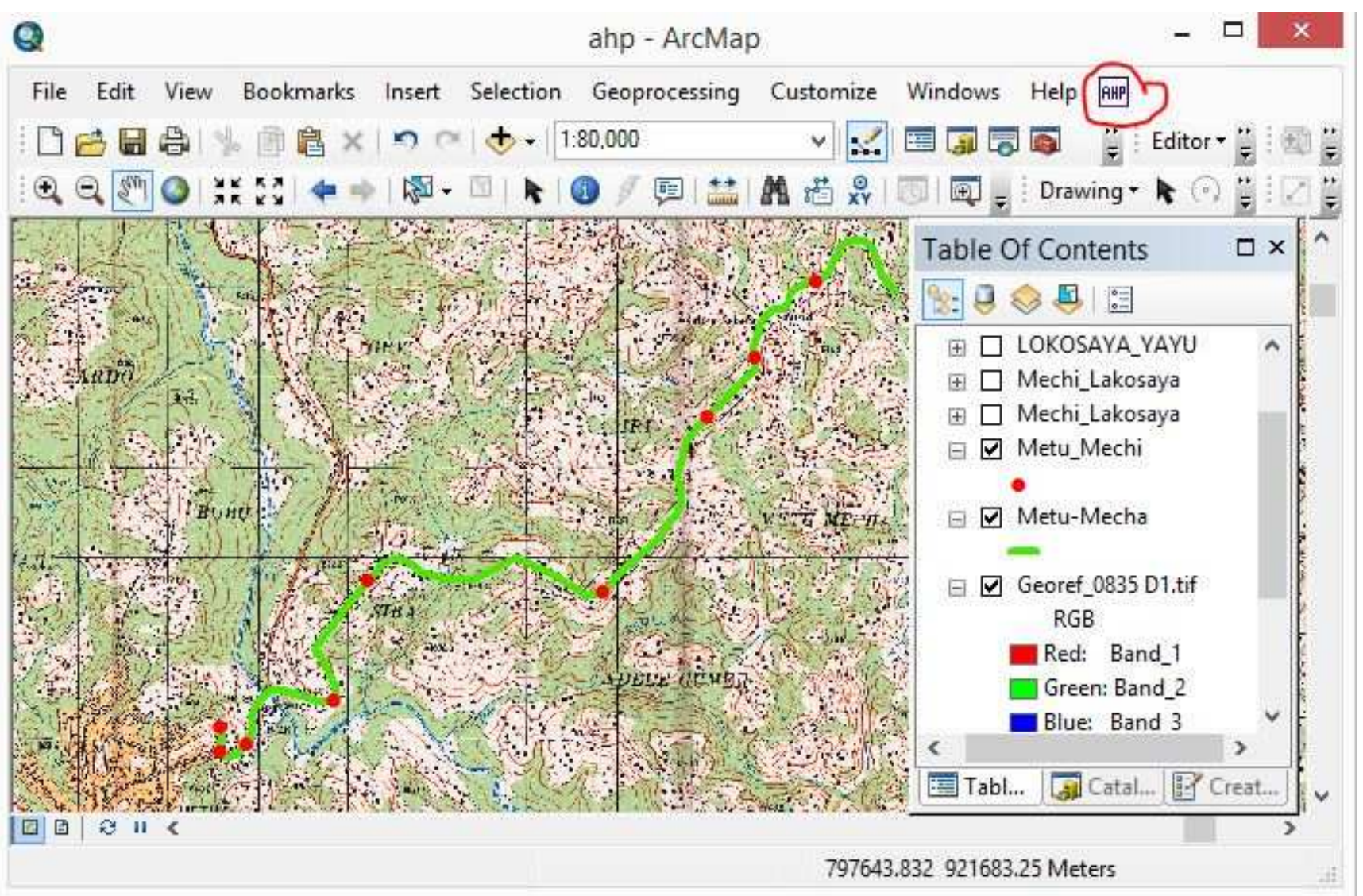

Figure 4. GPS location points of the inspection at Metu-Mechi road section.

Table 3. Road safety inspection of Metu to Mechi road section.

\begin{tabular}{|c|c|c|c|c|}
\hline \multirow{2}{*}{$\begin{array}{l}\text { GPS } \\
\text { Name }\end{array}$} & \multicolumn{2}{|c|}{ GPS Coordinates } & \multirow{2}{*}{ Description } & \multirow{2}{*}{ Figure illustrations } \\
\hline & Easting & Northing & & \\
\hline $\mathrm{MM}_{0}$ & 785593.407 & 919122.769 & Starting Point & \\
\hline $\mathrm{MM}_{1}$ & 785608.414 & 918856.777 & $\begin{array}{l}\text { Pavement distress (i.e. alligator cracking) } \\
\text { seen on the surface of the pavement }\end{array}$ & \\
\hline $\mathrm{MM}_{2}$ & 785904.733 & 918930.839 & $\begin{array}{l}\text { Traffic sign missed at the right side of road } \\
\text { shoulder }\end{array}$ & \\
\hline $\mathrm{MM}_{3}$ & 786861.435 & 919421.819 & $\begin{array}{l}\text { Pothole seen and traffic sign leg short in } \\
\text { length so the road user ie the driver unable to } \\
\text { see this informative sign. }\end{array}$ & \\
\hline
\end{tabular}




\begin{tabular}{|c|c|c|c|c|}
\hline \multirow{2}{*}{$\begin{array}{l}\text { GPS } \\
\text { Name }\end{array}$} & \multicolumn{2}{|c|}{ GPS Coordinates } & \multirow{2}{*}{ Description } & \multirow{2}{*}{ Figure illustrations } \\
\hline & Easting & Northing & & \\
\hline $\mathrm{MM}_{4}$ & 789873.651 & 920634.735 & $\begin{array}{l}\text { The pavement surface were undulated and } \\
\text { distressed to the right side of the road. The } \\
\text { aggregates and bitumen were disintegrated. }\end{array}$ & \\
\hline $\mathrm{MM}_{5}$ & 791031.921 & 922562.716 & Traffic sign leg shorten & \\
\hline $\mathrm{MM}_{6}$ & 791560.137 & 923231.557 & $\begin{array}{l}\text { Wide range of asphalt Transversal cracking } \\
\text { were seen on the pavement road surface. }\end{array}$ & $*$ \\
\hline $\mathrm{MM}_{7}$ & 792242.394 & 924080.781 & $\begin{array}{l}\text { Longitudinal ditch covered by vegetation } \\
\text { along the right side of the Asphalt road }\end{array}$ & \\
\hline $\mathrm{MM}_{8}$ & 793145.391 & 923972.983 & End point (near Mechi) & \\
\hline
\end{tabular}

\subsubsection{Mechi to Lakosaya Road Section}

This section of road commences from near Mechi village (793145.391, 923972.983), ends near Lakosaya village $(799486.9,922740.5)$ and has nine horizontal alignments with a minimum radius $275 \mathrm{~m}$. The maximum grade $-0.5 \%$ and the maximum grade $-6 \%$. In this context, the vertical alignment is within the limit of the standard value with regard to this context this road section experiences better safety. Along this road section traffic sign, sight distance obstruction and soil slide problems were observed as shown in the table 4 below.

Table 4. Road safety inspection at Mechi to Lakosaya road section.

\begin{tabular}{|c|c|c|c|c|}
\hline \multirow{2}{*}{ GPS Name } & \multicolumn{2}{|c|}{ GPS Coordinates } & \multirow{2}{*}{ Description } & \multirow{2}{*}{ Figure illustrations } \\
\hline & Easting & Northing & & \\
\hline $\mathrm{ML}_{0}$ & 793145.391 & 923972.983 & Starting Point & \\
\hline $\mathrm{ML}_{1}$ & 794069.7 & 923485.7 & Traffic sign missed at the right side of road shulder & \\
\hline $\mathrm{ML}_{2}$ & 794120.1 & 923353.5 & Sight distance obstruction near Yeadami & \\
\hline $\mathrm{ML}_{3}$ & 796729.6 & 922465 & Sight distance obstruction & \\
\hline $\mathrm{ML}_{4}$ & 798706.8 & 923210.6 & Improper placement of road traffic sign & \\
\hline $\mathrm{ML}_{5}$ & 799214.4 & 923093.4 & Non-functional traffic signal & \\
\hline $\mathrm{ML}_{6}$ & 793516.8 & 923729.2 & Soil slide problem & \\
\hline $\mathrm{ML}_{7}$ & 799486.9 & 922740.5 & End point (Lakosaya) & \\
\hline
\end{tabular}




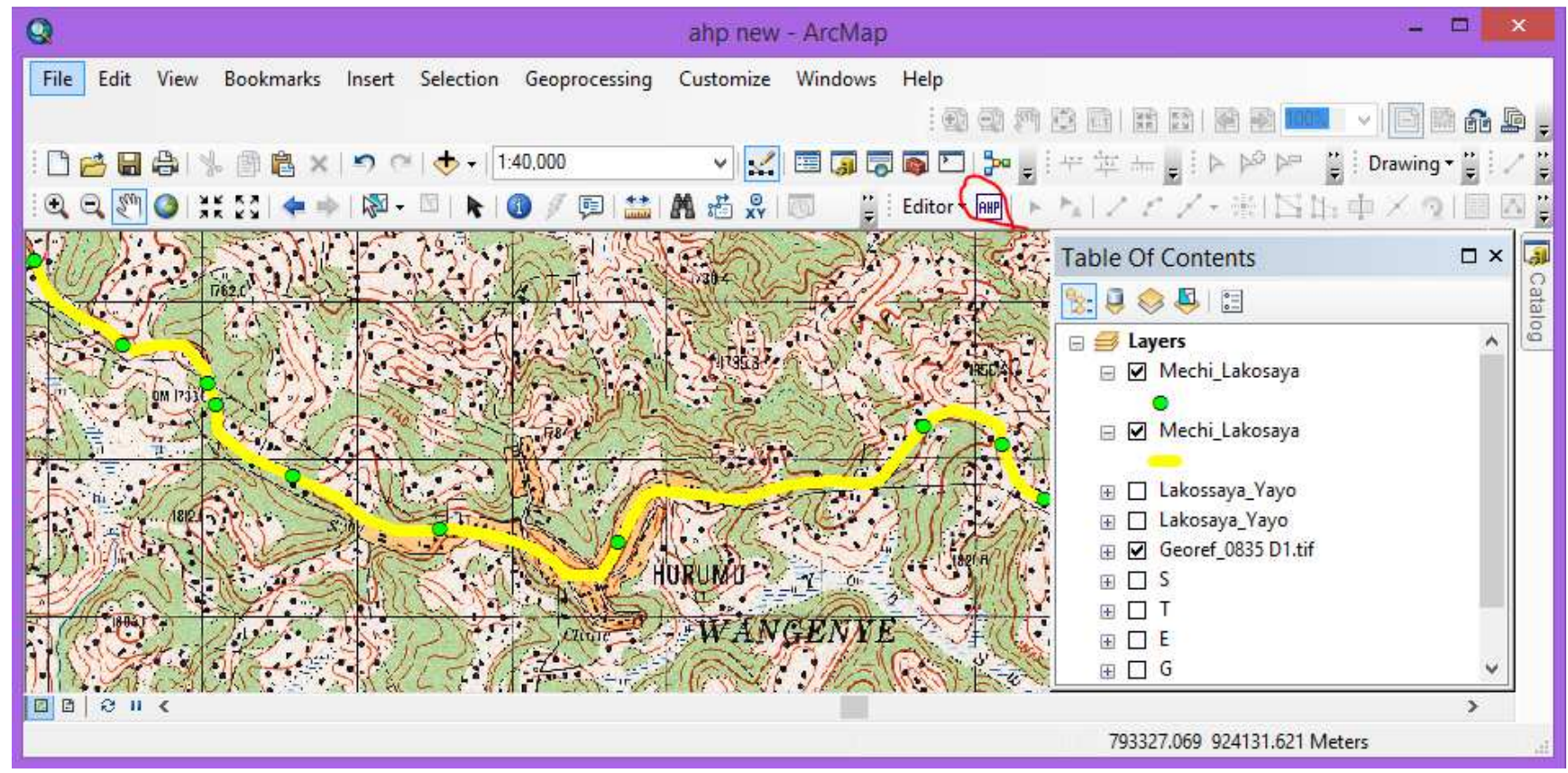

Figure 5. GPS location point map of the problematic area at Mechi to Lakosaya road section.

\subsubsection{Lakosaya to Yayo Road Section}

This road segment commences from Lakosaya village located at the coordinates $(799486.9,922740.5)$ and ends to Yayo town which is located at the coordinates $(799486.9,922740.5)$ with in Metu to Yayo road segment. Generally this section of road experiences more of road traffic related problems and some of were road geometric and road surface problems as shown in the table 5 .

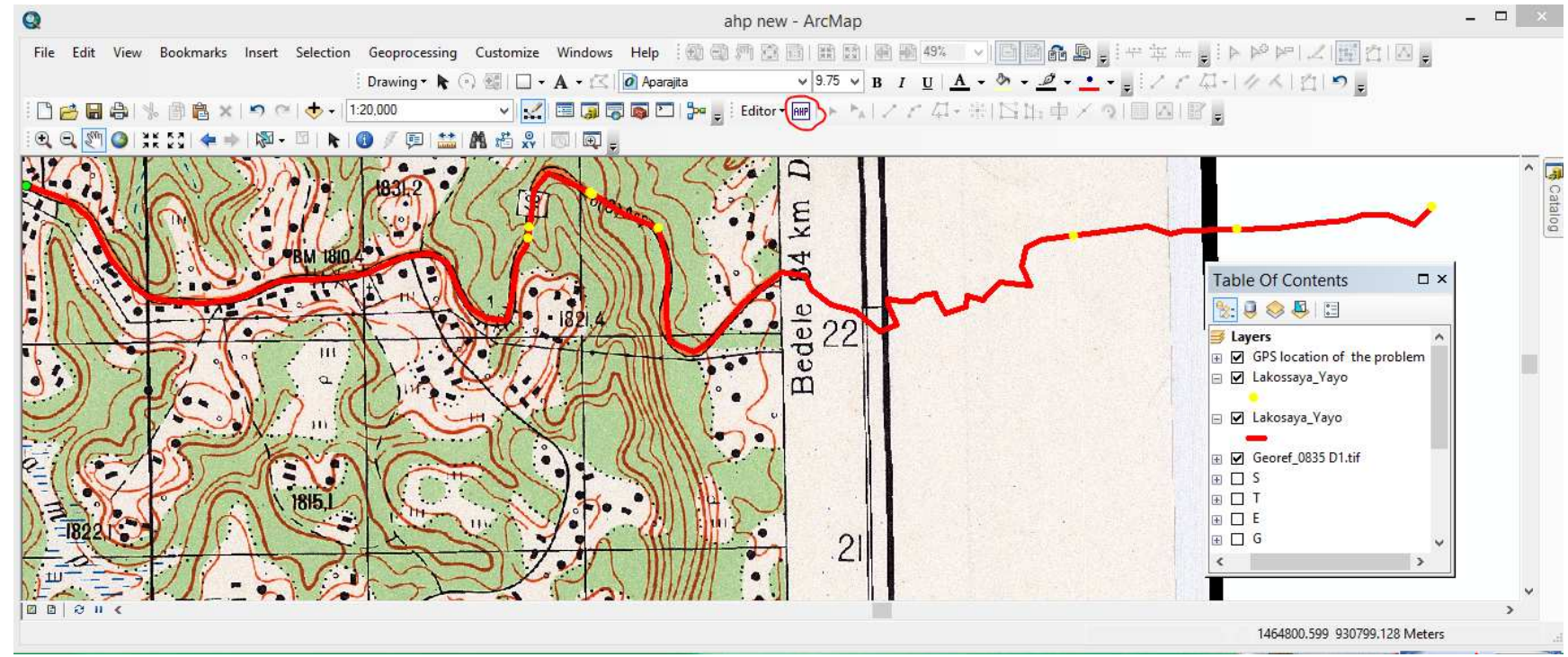

Figure 6. GPS location point map of the problematic area at Lakosaya to Yayo road section.

Table 5. Road safety inspection at Lakosaya to Yayo road section.

\begin{tabular}{lllll}
\hline \multirow{2}{*}{ GPS Name } & GPS Coordinates & Description & Figure illustrations \\
\cline { 2 - 5 } & Easting & Northing & Starting Point & \\
\hline MY $_{0}$ & 799486.9 & 922740.5 & & \\
MY $_{1}$ & 802107 & 922915 & faded sign & \\
\hline
\end{tabular}




\begin{tabular}{|c|c|c|c|c|}
\hline \multirow{2}{*}{ GPS Name } & \multicolumn{2}{|c|}{ GPS Coordinates } & \multirow{2}{*}{ Description } & \multirow{2}{*}{ Figure illustrations } \\
\hline & Easting & Northing & & \\
\hline $\mathrm{MY}_{2}$ & 802112 & 922909 & invisible traffic sign/improper faded & \\
\hline $\mathrm{MY}_{3}$ & 802456 & 922642 & missed traffic sign & \\
\hline $\mathrm{MY}_{4}$ & 801781 & 922520 & Invisible traffic sign & \\
\hline $\mathrm{MY}_{5}$ & 804324 & 921720 & Soil slide near Saqi river & \\
\hline $\mathrm{MY}_{6}$ & 805076 & 922081 & Sight distance obstruction & \\
\hline $\mathrm{MY}_{7}$ & 801752 & 922482 & Pavement distress $/ 1.5 * 0.75$ & \\
\hline $\mathrm{MY}_{8}$ & 793145.391 & 923972.983 & End point & \\
\hline
\end{tabular}

\subsection{Analytical Hierarchical Process Analysis of Judgment Values}

The case of road safety problem needs to be evaluated in terms of four decision criteria i.e. geometry of the road, traffic control, road surface, road side environment per the road section in the road segment using AHP. The significant factors which contribute the occurrences of road safety risk presented pairwise comparisons were done depending on the judgment values taken from the questionnaires filled by the concerned focus groups. For the factors which its cause is high safety risk assigned the lowest value and vice versa. The judgment values were taken from the focus group. 
Table 6. Summary of level l analytical hierarchy process for criteria.

\begin{tabular}{|c|c|c|c|c|c|c|c|c|c|}
\hline \multicolumn{5}{|c|}{ Judgment Matrixes } & \multirow{2}{*}{$\begin{array}{l}\text { Step (1-3) } \\
\text { SUM } \\
\end{array}$} & \multirow{2}{*}{$\begin{array}{l}\text { Step-4 } \\
\text { PV } \\
\end{array}$} & \multirow{2}{*}{$\begin{array}{l}\text { Step-5 } \\
\Lambda \max \\
\end{array}$} & \multirow{2}{*}{$\begin{array}{l}\text { Step-6 } \\
\text { CI } \\
\end{array}$} & \multirow{2}{*}{$\begin{array}{l}\text { Step-7 } \\
\text { CR } \\
\end{array}$} \\
\hline Level1 & $S$ & $T$ & $E$ & $G$ & & & & & \\
\hline \multicolumn{10}{|c|}{ Metu to Mechi Road section } \\
\hline $\mathrm{S}$ & 1 & 2 & 5 & 3 & 1.9154 & 0.478 & \multirow{4}{*}{4.2258} & \multirow{4}{*}{0.07462} & \multirow{4}{*}{0.082} \\
\hline $\mathrm{T}$ & 0.5 & 1 & 3 & 2 & 1.0732 & 0.268 & & & \\
\hline $\mathrm{E}$ & 0.2 & 0.33 & 1 & 2 & 0.5399 & 0.134 & & & \\
\hline G & 0.3 & 0.5 & 0.5 & 1 & 0.4706 & 0.117 & & & \\
\hline \multicolumn{10}{|c|}{ Mechi to Lakosaya Road section } \\
\hline $\mathrm{S}$ & 1 & 0.25 & 1 & 2 & 0.6404 & 0.160 & \multirow{4}{*}{4.1736} & \multirow{4}{*}{0.05788} & \multirow{4}{*}{0.064} \\
\hline $\mathrm{T}$ & 4 & 1 & 3 & 5 & 2.1387 & 0.534 & & & \\
\hline $\mathrm{E}$ & 1 & 0.33 & 1 & 5 & 0.9161 & 0.229 & & & \\
\hline G & 0.5 & 0.2 & 0.2 & 1 & 0.3046 & 0.076 & & & \\
\hline \multicolumn{10}{|c|}{ Lakosaya to Yayo road section } \\
\hline S & 1 & 0.2 & 1 & 1 & 0.6159 & 0.1539 & \multirow{4}{*}{4.1462} & \multirow{4}{*}{0.04875} & \multirow{4}{*}{0.054} \\
\hline $\mathrm{T}$ & 5 & 1 & 2 & 2 & 1.8795 & 0.4698 & & & \\
\hline $\mathrm{E}$ & 1 & 0.5 & 1 & 1 & 0.7522 & 0.1880 & & & \\
\hline G & 1 & 0.5 & 1 & 1 & 0.7522 & 0.1880 & & & \\
\hline
\end{tabular}

$\mathrm{PV}=$ the priority vector, $\lambda_{\max }=$ the principal Eigen value, $\mathrm{CI}=$ Consistency index, $\mathrm{CR}=$ consistency ratio.

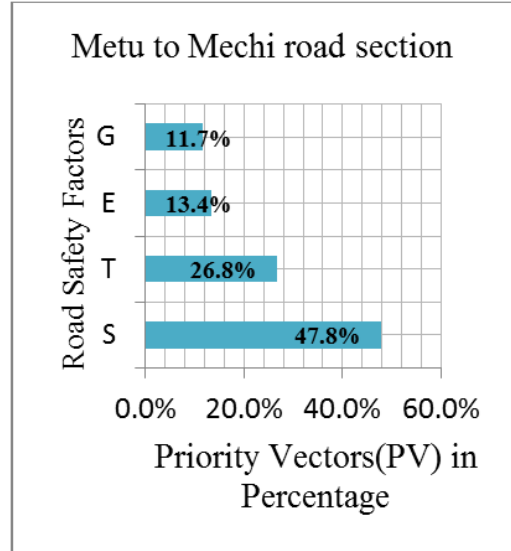

(a)

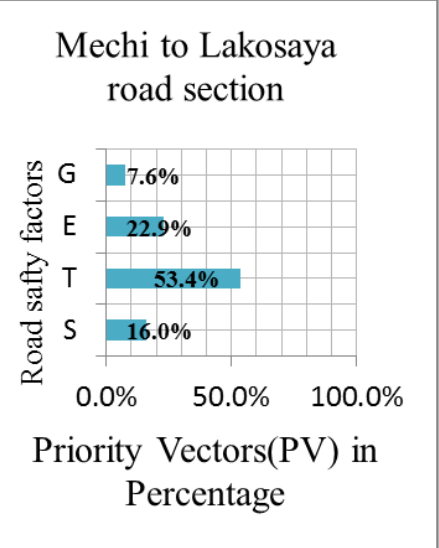

(b)

\section{Lakosaya to Yayo road section}

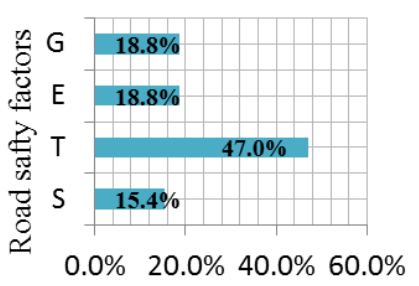

Priority Vectors $(\mathrm{PV})$ in Percentage

Figure 7. Road safety factors in percentage of Priority vectors from Metu to Yayo road segment.

The consistency values, $\mathrm{CR}=1.1 \%<4.1 \%<7 \%$ are less than the threshold value of $\mathrm{CR}=10 \%$. Therefore, the judgment is consistent and acceptable! and from the result shown in the above table 6 and figure 7 (a) one can deduce that the road traffic control factors cover $47.8 \%$ with that of the other factors hence it is the most significant factor which contributes high road safety risk along Metu to Mechi road section in the future; traffic control $(26.8 \%)$, road side environment condition (13.4\%) and road geometry (11.7\%) followed respectively.

Similarly, from the priority vector value shown in the above figure7 (b) the road traffic control factors accounts around $54 \%$ for the road risk when it is compared to the other factors, hence it is the most significant factor which contributes high road safety risk at Mechi to Lakosaya road; road side environment condition (18\%) road surface condition $(16.9 \%)$, and road geometry $(9.5 \%)$ followed respectively. the road from Mechi town to the small village Lakosaya is more or less vulnerable to road safety risk due to traffic control facilities condition factors which covers $47 \%$, but the road side environmental condition and geometry of the road factors share the same value $18.8 \%$, and the road surface condition factors cover $15.4 \%$ which has less effect on the road safety risk.

Table 7. Level 1 analytical hierarchy process PV over all the criteria on the road segment.

\begin{tabular}{|c|c|c|c|c|c|c|c|c|c|}
\hline \multicolumn{5}{|c|}{ Judgment Matrixes } & \multirow{2}{*}{$\begin{array}{l}\text { Step (1-3) } \\
\text { SUM }\end{array}$} & \multirow{2}{*}{$\begin{array}{l}\text { Step-4 } \\
\text { PV }\end{array}$} & \multirow{2}{*}{$\begin{array}{c}\text { Step-5 } \\
\text { Mmax }\end{array}$} & \multirow{2}{*}{$\begin{array}{l}\text { Step-6 } \\
\text { CI } \\
\end{array}$} & \multirow{2}{*}{$\begin{array}{l}\text { Step-7 } \\
\text { CR } \\
\end{array}$} \\
\hline Level1 & $S$ & $T$ & $E$ & $G$ & & & & & \\
\hline \multicolumn{10}{|c|}{ Metu to Yayo road segment } \\
\hline $\mathrm{S}$ & 1 & 2 & 5 & 3 & 0.9333 & 0.2333 & \multirow{4}{*}{4.2333} & \multirow{4}{*}{0.0777} & \multirow{4}{*}{0.0864} \\
\hline $\mathrm{T}$ & 0.5 & 1 & 3 & 2 & 1.5333 & 0.3833 & & & \\
\hline $\mathrm{E}$ & 0.2 & 0.33 & 1 & 2 & 0.7666 & 0.1916 & & & \\
\hline G & 0.3 & 0.5 & 0.5 & 1 & 0.7666 & 0.1916 & & & \\
\hline
\end{tabular}




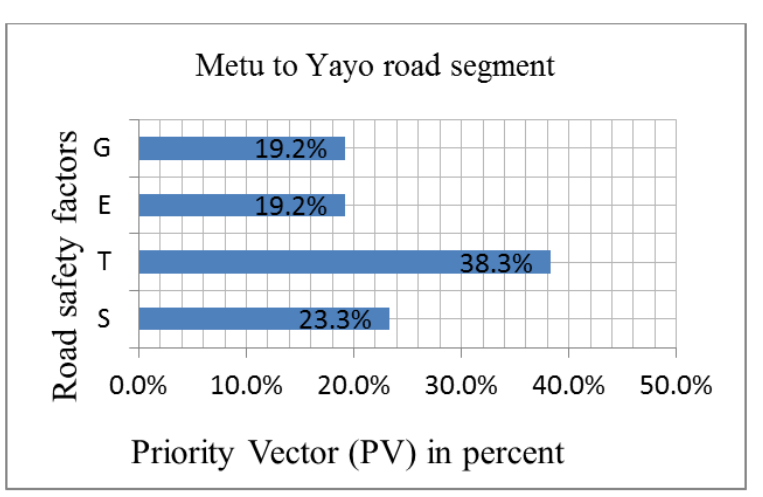

Figure 8. Analytical Hierarchy Process over the entire road length of the road.

The judgment is accepted since the value of consistency ratio 0.08 is less than the threshold value 0.1 .

From table 7 and figure 8 shown above level one analysis done over the entire road segment. As a result, the road traffic control factors $(28.3 \%)$ take the major portion in increasing the road safety risk, road surface factor $(23.3 \%)$, road side environment and road geometry factors (19.2) contribute for the road safety risk respectively.

\subsection{Road Section Prioritization}

In section 8.2 one level AHP analysis has been made to identify the most significant factor which contributes high road safety risk, in this section depending on the four major factors two levels of AHP analysis were done in order to identify the current performance of road section in a sense a road section with better facilities. This enables which road section is better in accordance with good highway facilities and which road section requires regular road safety inspection to minimize the occurrence of road safety risk. Similar AHP analysis done based on the group judgment and the lowest value is selected and used for the result which contribute less effect on the road safety and vice versa.

The pair wise comparison of level-2 judgment matrix for the four factors over the road segment

Table 8. Level 2 AHP analysis output for Metu to Yayo road segment (Weighted PV).

\begin{tabular}{|c|c|c|c|c|c|c|c|c|}
\hline \multicolumn{3}{|c|}{ Judgment Matrixes } & \multirow{2}{*}{\multicolumn{2}{|c|}{$\begin{array}{l}\text { Step (1-3) } \\
\text { SUM }\end{array}$}} & \multirow{2}{*}{$\begin{array}{l}\text { Step-4 } \\
\text { PV }\end{array}$} & \multirow{2}{*}{$\begin{array}{l}\text { Step-5 } \\
\Lambda \max \end{array}$} & \multirow{2}{*}{$\begin{array}{l}\text { Step-6 } \\
\text { CI }\end{array}$} & \multirow{2}{*}{$\begin{array}{l}\text { Step-7 } \\
\text { CR }\end{array}$} \\
\hline Level1 & $M M$ & $M L$ & & & & & & \\
\hline \multicolumn{9}{|c|}{ Paired comparison with respect to road surface factors } \\
\hline MM & 1 & 2 & 3 & 1.6169 & 0.538 & \multirow{3}{*}{3.0108} & \multirow{3}{*}{0.0054} & \multirow{3}{*}{0.009} \\
\hline ML & 0.5 & 1 & 2 & 0.89182 & 0.297 & & & \\
\hline LY & 0.333 & 0.5 & 1 & 0.49119 & 0.163 & & & \\
\hline \multicolumn{9}{|c|}{ Paired comparison with respect to road traffic control factors } \\
\hline MM & 1 & 2 & 5 & 1.6677 & 0.555 & \multirow{3}{*}{3.0708} & \multirow{3}{*}{0.0354} & \multirow{3}{*}{.061} \\
\hline ML & 0.5 & 1 & 5 & 1.0611 & 0.353 & & & \\
\hline LY & 0.2 & 0.2 & 1 & 0.2710 & 0.090 & & & \\
\hline \multicolumn{9}{|c|}{ Paired comparison with respect to road side environment factors } \\
\hline MM & 1 & 2 & 5 & 0.3308 & 0.110 & \multirow{3}{*}{3.0685} & \multirow{3}{*}{0.03428} & \multirow{3}{*}{0.059} \\
\hline ML & 0.5 & 1 & 5 & 1.6312 & 0.543 & & & \\
\hline LY & 0.2 & 0.2 & 1 & 1.0378 & 0.346 & & & \\
\hline \multicolumn{9}{|c|}{ Paired comparison matrix with respect to road geometry factors } \\
\hline MM & 1 & 0.333 & 0.5 & 0.50940 & 0.169 & \multirow{3}{*}{3.0203} & \multirow{3}{*}{0.0101} & \multirow{3}{*}{0.018} \\
\hline ML & 3 & 1 & 1 & 1.32863 & 0.442 & & & \\
\hline LY & 2 & 1 & 1 & 1.16196 & 0.387 & & & \\
\hline
\end{tabular}

$\mathrm{MM}=$ Road from Metu to Mechi Village entrance. MM=Road from Mechi village entrance to Lakosaya village, LY=Road from Lakosaya Village to Yayo town entrance.

Table 9. Summary of composite weight (CW) of each road section.

\begin{tabular}{llllll}
\hline Alternate choice & S & T & E & G & $\boldsymbol{C W}=\boldsymbol{\Sigma}(\boldsymbol{P V} \boldsymbol{c} * \boldsymbol{P V} \boldsymbol{r})$ \\
\hline $\mathrm{PVc} / \mathrm{PVr}$ & 0.33 & 0.44 & 0.12 & 0.11 & \\
$M M$ & 0.538 & 0.555 & 0.110 & 0.169 & 0.367 \\
$M L$ & 0.297 & 0.353 & 0.543 & 0.442 & 0.177 \\
$L Y$ & 0.163 & 0.090 & 0.346 & 0.387 & 0.453 \\
\hline
\end{tabular}

$\mathrm{CW}$ :-Composite Weight, $\mathrm{CW}=\Sigma[\mathrm{PV}$ of the road sections with respect to each factor (level 2$) * \mathrm{PV}$ of over the entire road segment], PVc/PVr - Priority Vector of level 2 (with respect to each factor and Level 1 (over the road segment).

To identify which road section is with the better safety or in the worse condition the overall composite weight of each road sections must be computed depending on weight of level 1 and level 2 criteria. The PV is taken from the priority vectors which are computed under prioritizing the road section for level 1 and the second priority vector $(\mathrm{PV})$ is taken from road section with respect to each criteria.

The overall consistency ratio, $C R w$ (look at equation (5) is computed to determine whether the composite weight/ the hierarchy is consistent or not using the ratio of weighted consistency index (CI) and weighted random consistency index (RI).

$$
C R w=\frac{\lfloor 0.0279 * 1+0.0054 * 0.32873+0.0354 * 0.44288+0.0342 * 0.11821+0.0101 * 0.11019]}{[0.9 * 1+0.58 * 0.32873+0.58 * 0.44288+0.58 * 0.11821+0.58 * 0.11019]}=0.0354<0.1
$$


Therefore the judgment is accepted.

From the composite weight analysis result shown in the table 9 and figure 9 the road from Lakosaya to Yayo road section is the found to be in a better condition followed then road from Metu to Mechi section, but Metu to Lakosaya road section is found in a worse condition since it has less weight when it is compared with the other alternatives along the given road segment. The road with high composite weight ratio shows the road the road become less prone to road safety risks but not mean that it is extremely has better traffic control facilities and good road surface.

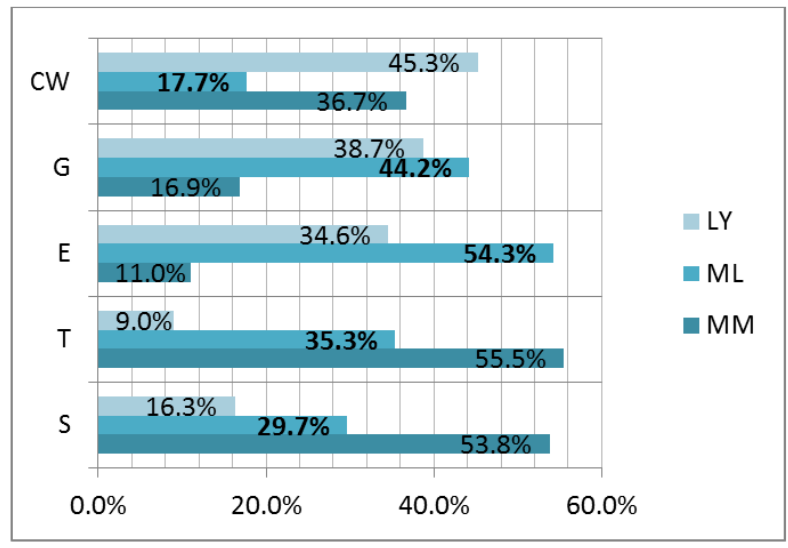

Figure 9. Composite weight (CW) of each road section.

\section{Conclusion}

From road safety inspection result the road segment (Metu-Yayo) experiences early stages of pavement distress, road section traffic sign, sight distance obstruction, and soil slide related problems were observed, which increases the occurrence of road traffic accidents. For this research work pair wise comparison of Analytical Hierarchy Process based analysis was done on Metu to Yayo road to identify and prioritize road sections in the study area. As a result, the road traffic control factors (28.3\%) takes the major portion in increasing the road safety risk and depending on summary of composite weight $(\mathrm{CW})$ result of each road section the road from Lakosaya to Yayo road section $(45.3 \%$, ) is the found in a better condition than road from Metu to Mechi section (36.7\%), but Mechi to Lakosaya road section is found in a worse condition since its composite weight value is $17.7 \%$. AHP method based analysis mechanism of proactive road safety inspection has a great deal of importance to identify which section of the road is found in better condition and which is in worse condition, and what types of road safety factors will be a cause for the risk of road safety to reduce road safety risk and the occurrences of future road traffic accidents in this study area.

\section{References}

[1] World Health Organization, Global status report on road safety, 2015.

[2] World Health Organization, Global status report on road safety, time for action, 2009.

[3] South African Road Safety Audit Manual; 2nd Edition, May, 2012 (still it has no new update).

[4] Addis Ababa City Roads Authority; Road Inventories. 2016.

[5] Ahmeda Ishtiaque, Othman Che Puana, Che Ros Ismaila; a Comparative Review of Road Safety Audit Guidelines of Selected Countries, October, 2013.

[6] ERA (September 2004), Ethiopian Roads Authority, Road safety audit manual (draft) still it has no up dated.

[7] FHWA, Road safety audit guidelines, FHWA-SA-06-06, 2006.

[8] NCHRP Synthesis 336, Road Safety Audits, A Synthesis of Highway Practice, USA, July 2004.

[9] Road safety inspection Manual for conducting RSI; Vienna, Nov. 2014.

[10] Cardoso João L. (LNEC), Christian Stefan (KfV), Rune Elvik \& Michael Sørensen (TØI); Road Safety Inspections: best practice and implementation plan. January, 2005.

[11] A. kotkar, O. Gholap, N. Shinde. et al, Road Safety Audit, International Journal of Engineering Research and Technology, Vol. 7 Issue 04, April-2018.

[12] N. Naveen, M. Rajesh, M. Sirinivas, Md. Fassioddin, Road Safety Audit of a Rural Road. International Journal of Civil Engineering and Technology, 8 (4), 2017, pp. 752-761.

[13] World Health Organization, Global status report on road safety, 2018.

[14] Triantaphyllou. E and Stuart H. Mann; Using the Analytic Hierarchy Process for Decision Making In Engineering Applications: Some Challenges, International Journal of Industrial Engineering: Applications and Practice, Vol. 2, No. 1, pp. 35-44, and 1995 .

[15] T. L. Saaty, Decision making with the analytic hierarchy process' international J. Services Sciences, Vol. 1, No. 1, pp. 83-98, 2008. 